ACTA THERIOLOGICA

Vol. 23, 4: 75-98, 1978

\title{
Seasonal and Sexual Differences in Absolute and Relative Growth in Microtus montebelli ${ }^{1}$
}

\author{
Yukibumi KANEKO
}

Kaneko Y. 1978: Seasonal and sexual differences in absolute and relative growth in Microtus montebelli. Acta theriol., 23, 4: 75-98 [With 1 Table \& 10 Figs.].

A study of external and cranial growth in Microtus montebelli was carried out on cultivated land in Kyoto, western Honshu, Japan. Specimens were trapped bi-monthly from May, 1971 through March, 1972. Separation of each monthly population into different generations was made using the correlation of the following two methods: (1) polymodal frequency distributions of condylo-basal length in each month were separated usi.g arithmetic probability papers, and (2) age group method in skulls and ratio diagram method were introduced. There existed differences between the growth rate of specimens born in spring (S-generation) and the rate of those born in fall (Fgeneration). The differences in absolute growth rates between both sexes in S-generation were generally greater than the differences between both sexes in F-generation. Furthermore, the differences between the two generations in males were greater in most characters than between the two generations in females. The growth rate in male S-generation was the largest compared with the three other curves: i.e., male F-generation, female S-generation and female F-generation. Compared with females, the braincase parts in males were hypermorphic, especially in size, paraoccipital process and lamdoidal and mastoid-exoccipital crests. Sexual differences in relative growth in most parts became greater as H\&BL and CBL increased. In males the braincase part of skull grew greatly in S-generation than in F-generation, while the diastema part increased largely in F-generation than in S-generation. In both absolute and relative growth, females showed smaller seasonal variation than males.

[Biol. Inst., Fac, Educ., Kagawa Univ., Takamatsu 760, Japan.]

\section{INTRODUCTION}

Many workers have drawn attention to the phenomenon of seasonal variations that external size correlates with the birth date of voles; i.e., growth is more rapid in spring-born than in summer- and fall-born young. The phenomenon has been described in several species of Microtus (B a rbehenn, 1955; Southern, 1964; T ast, 1966; Martinet \& Spitz, 1971; Pokrovski j, 1971; Brown, 1973). $\mathrm{S}$ c h w a r z et al., (1964) discussed the phenomenon in rodents and certain other mammals from the viewpoint of senescence. P in te r (1968) and M a r tinet et al. (1971) showed that combinations of dietary type

1 Contribution No. 35 from the Biological Institute, Faculty of Education, Kagawa University. 
and photoperiods had an effect on the growth of $M$. montanus and $M$. arvalis. Evan s (1973) measured seasonal changes of food quality and related it to the changes of body weight in $M$. agrestis.

However, we have as yet no information as to the phenomenon in the Japanese field vole, Microtus montebelli (M ilne-Edwards, 1872). The object of the present paper is to investigate sexual and seasonal differences of absolute growth and relative growth in external and cranial characters of this vole. This work is a continuation of the study on the reproduction of the Japanese field vole at Iwakura, Kyoto, Japan (K a n e k o, 1976).

\section{MATERIALS, STUDY AREA AND PERIODS}

The specimens used in this study are the same as described in the previous paper (K a n e k o, 1976). Readers are referred to the paper for fuller information on the study area and trapping method. Field work was carried out in the following periods: May 13-16, July 19-24, September 24-27, and November 18-21, 1971; January 14-17, and March 11-14, 1972. The total numbers of voles trapped were 206 males and 171 females. Since several skulls were damaged by traps, certain measurements could not be taken on them. The number of specimens used is shown in each figure and table.

\section{MEASUREMENTS}

Body weight ${ }^{1}(B W)$, head and body length $(H \& B L)$, tail length ${ }^{2}(T L)$, hind foot length (HFL) and ear length $(E L)$ of the vole were recorded as soon as possible after removing the animals from traps. Subsequently, these specimens were stocked in 10 per cent formaldehyde solution. The skulls were cleaneid after boiling in water. All dimensions of the skull were measured directly from the skulls with dial-caliper within $0.1 \mathrm{~mm}$. Measurements were taken as described below and illustrated in Fig. 1. Paired structures were measured on the left side. 1. Condylo-basal length $(C B L)$ : distance between occipital condyle and anterior point of premaxillae.

2. Condylo-zygomatic length $(C-Z)$ : distance between occipital condyle and anteriosuperior edge of zygomatic process of maxillae.

3. Condylo-molar 1 length $\left(C-M^{1}\right)$ : distance between occipital condyle and anterior edge of $\mathrm{M}^{1}$.

4. Incisive-molar 3 length $\left(I-M^{3}\right)$ : distance from the most anterior point of incisor to the most posterior edge of $\mathbf{M}^{3}$.

5. Length of diastema (Dias): distance from posterior edge of incisive alveolus to anterior edge of alveolar space of molar raw.

6. Molar length $(M L)$ : distance from the most anterior edge of $\mathrm{M}^{1}$ to the most posterior edge of $\mathbf{M}^{3}$.

1 Body weight substracting the weight of embryos was used that of each pregnant female.

2 This length was taken from the anus to the tip of tail vertebrae. 
7. Length of incisive foramen (IFL): maximum length of palatine slit.

8. Length of nasal $(N L)$ : maximum length of nasal bone.

9. Zygomatic width $(\mathrm{ZW})$ : maximum spread of zygomatic arches.

10. Interorbital width (IOW): least diameter of frontal bones between orbits.

11. Paramastoid process width $(\operatorname{ParPrW})$ : distance between the most outer edges of paramastoid process.
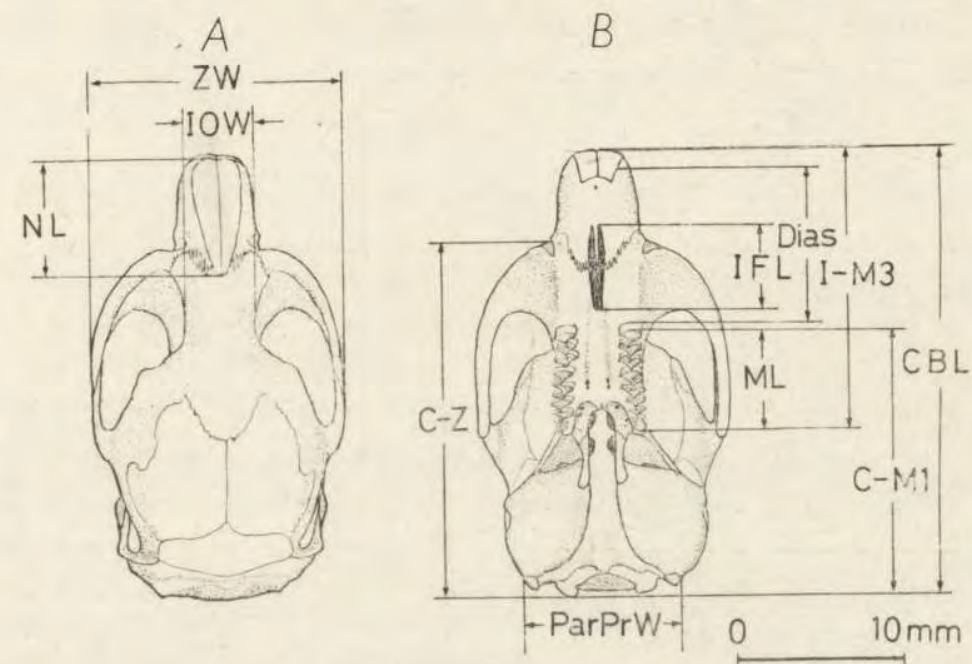

Fig. 1. Dorsal (A) and ventral (B) views of skull of Microtus montebelli illustrating dimensions explained in text.

\section{SEPARATION OF EACH MONTHLY POPULATION INTO SEVERAL AGE COMPOSITIONS USING TWO METHODS}

In the study of seasonal variation in a wild state, changes that occur with increasing age of voles are perhaps the most troublesome. Since the teeth of Microtus grow continuously, the appearance of root cannot be used for an age indicator. Although eye lens weight has been taken to determine the age of $M$. arvalis ( $\mathrm{M}$ a r tinet, 1966; A d a m c z ewska-Andrzejewska, 1973a), it has not been as yet applied to other species of Microtus.

Methods used in the present study are as follows: (1) polymodal frequency distributions of condylo-basal length in each month were separated by the method of Cassie (1954) using arithmetic probability papers (Fig. 2). There was zero or one break, which divided the monthly population into one or two different age classes, respectively. Young animals just weaned were distinguished by size and pelage from other age classes in the May and the November populations. (2) Age group method in skulls (Snyder, 1954) and ratio diagram method (Simpson, 1941; Snyder, 1954) were introduced as the other 


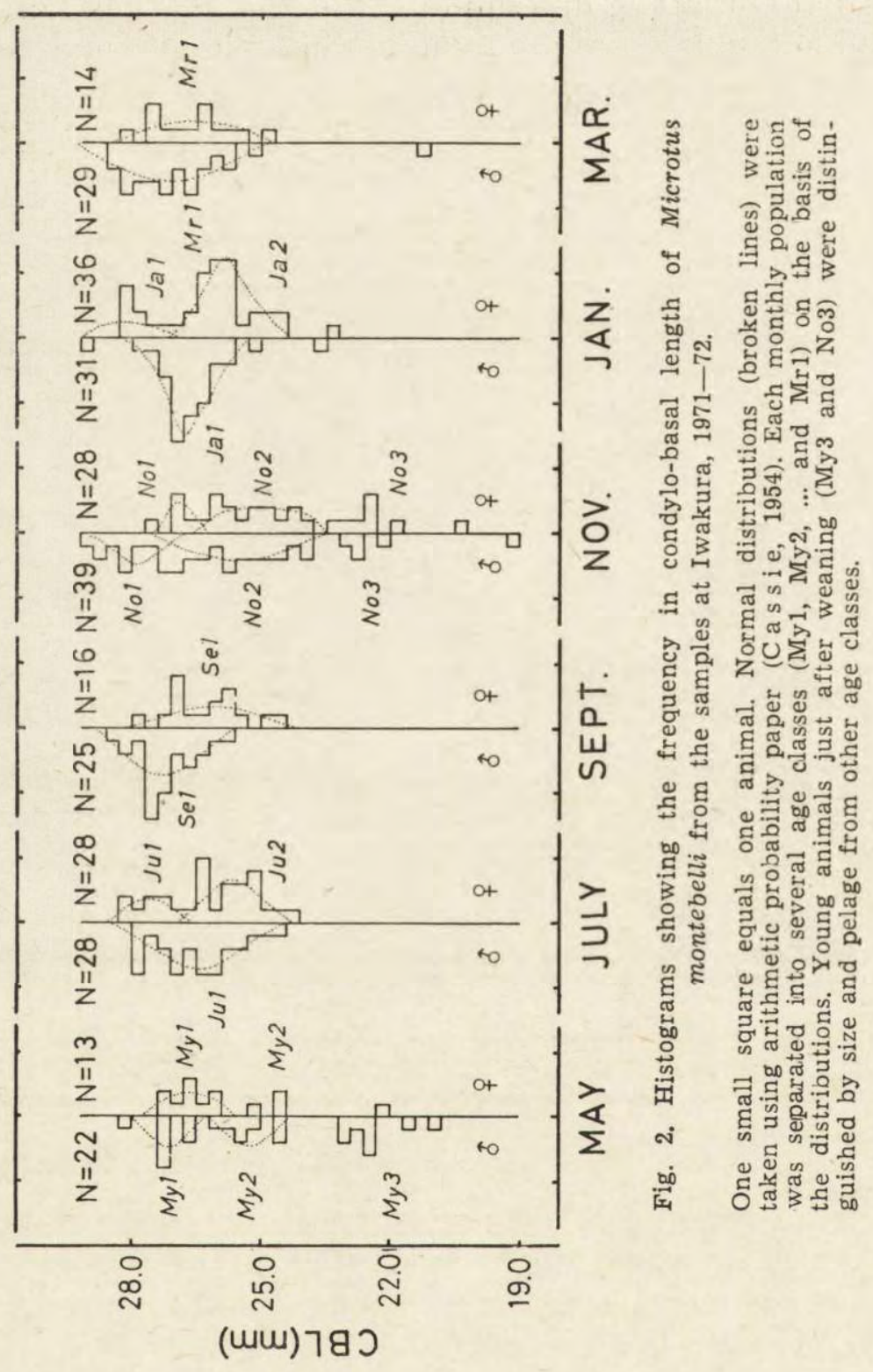


method. Three characters, lambdoidal crest, mastoid-exoccipital crest and paraoccipital process, were selected. In each skull examined, the position of the process and each crest was given a value from one to four in order of increasing development. The three index figures were then totaled to determine the age group to which the specimens belong-

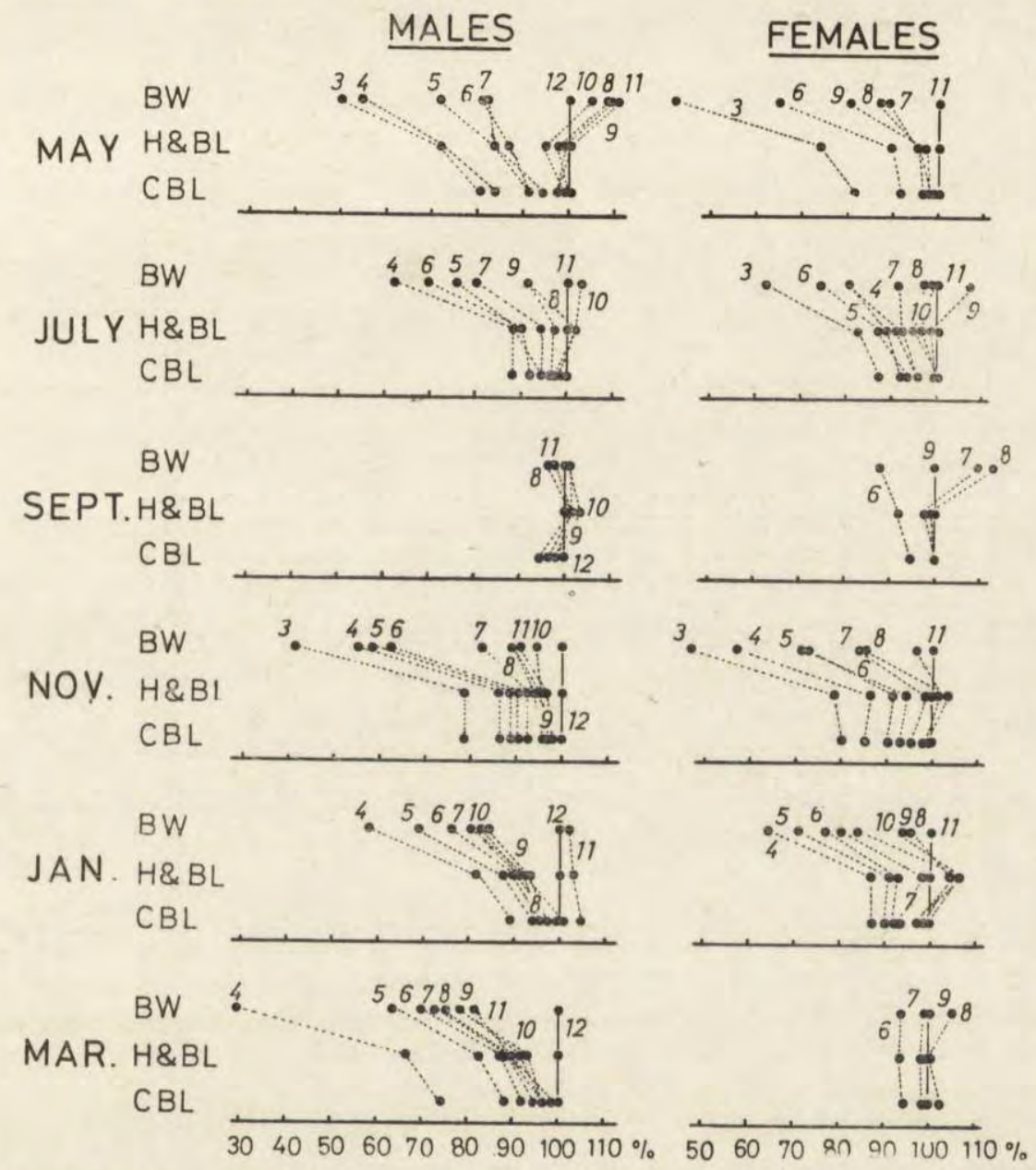

Fig. 3. Percentage diagrams of dimensions and weight in Microtus montebelli. Age groups are shown in $3,4, \ldots$ and 12 . Mean values of the dimensions and weight at each age were used in plotting. Further explanations were shown in text and Sny der (1954).

ed. There resulted ten groups, the youngest one represented by three and the oldest by twelve. A detailed description of the method is given by $\mathrm{Snyde} r$ (1954). The ratio diagram method compares the proportion of skull and external measurements of each age group with 
that of the largest age group in each month (Fig. 3). The graphic method of the diagram was first developed by Simpson (1941) and revised by Snyder (1954). Readers are referred to these papers for further explanations. It can be readily seen from Fig. 3 that several age groups were arranged together with respect to proportional differences, except the November female population.

There were close relationships between age classes by method (1) and proportional groups by method (2), except for a few animals (Fig. 4).

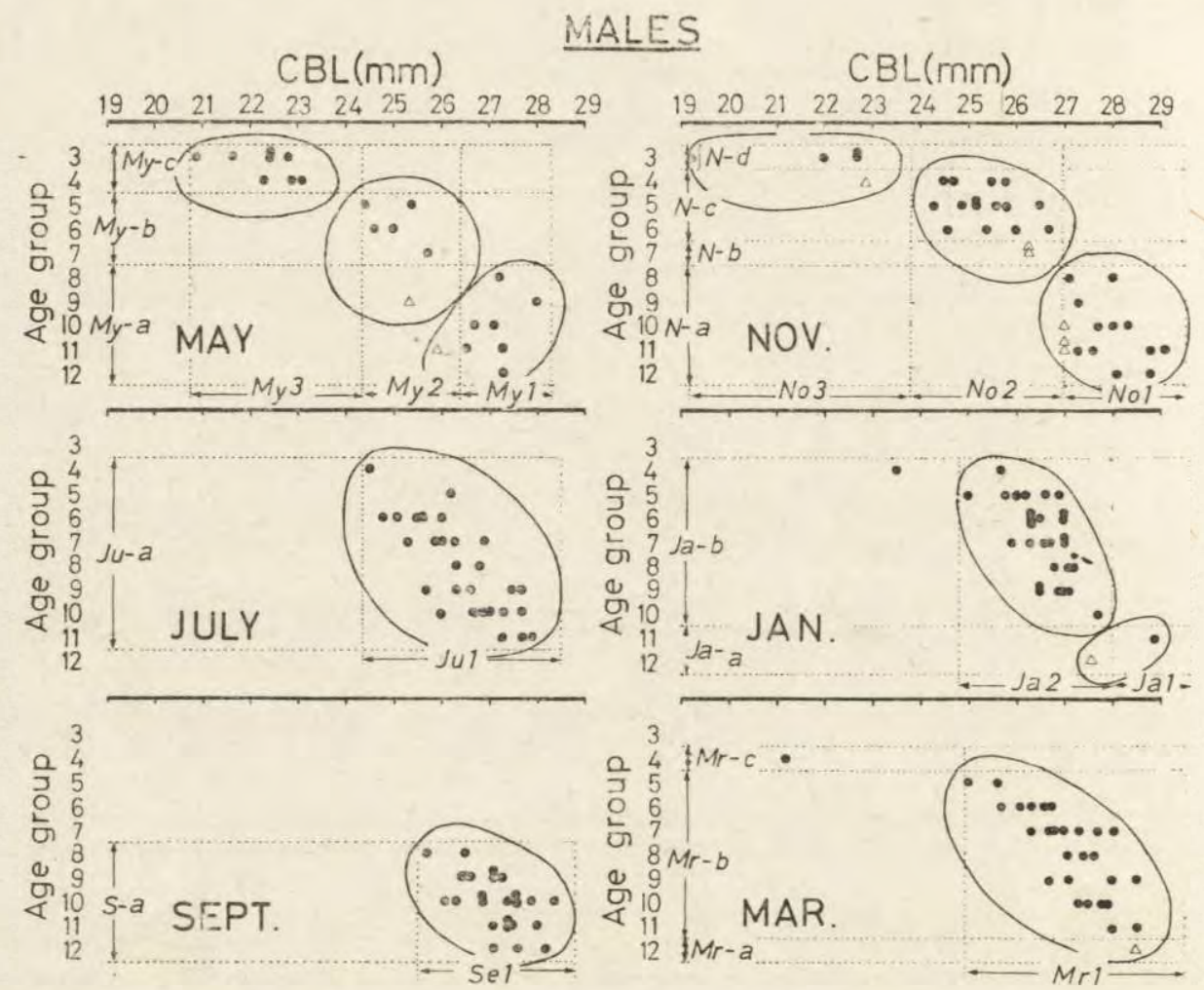

Fig. 4. Relationships between age classes (Fig. 2) and proportion groups (Fig. 3). My1, My, ... and Mr1 indicate age classes based on Fig. 2. My-a, My-b, My-c, ..., $\mathrm{Mr}-\mathrm{a}, \mathrm{Mr}-\mathrm{b}$ and $\mathrm{Mr}-\mathrm{c}$ show proportion groups based on the proportional differences in Fig. 3. Open triangles were out of correlation between age classes and proportion groups. Circles indicate different age compositions in each monthly population.

From these analyses it is concluded that specimens in each circle (Fig. 4) belong in the same age composition in each monthly population.

When each mean value of specimens in each circle was graphed against six sampling times, two growth curves were obtained: the one began from May and the other started in November. In the previous paper (K a neko, 1976), the breeding of the vole at Iwakura was described 
as occurring primarily in spring (May-June) and fall (September-December) with sporadic reproduction during winter (January-February) and an aestival intermission (July-August). Therefore, the growth curve beginning in May is regarded as that of spring born animals (S-generation) and that starting in November is considered to be that of fall born animals (F-generation). The term "generation" was first used to indicate the existence of a group of characters differentiating individuals born at

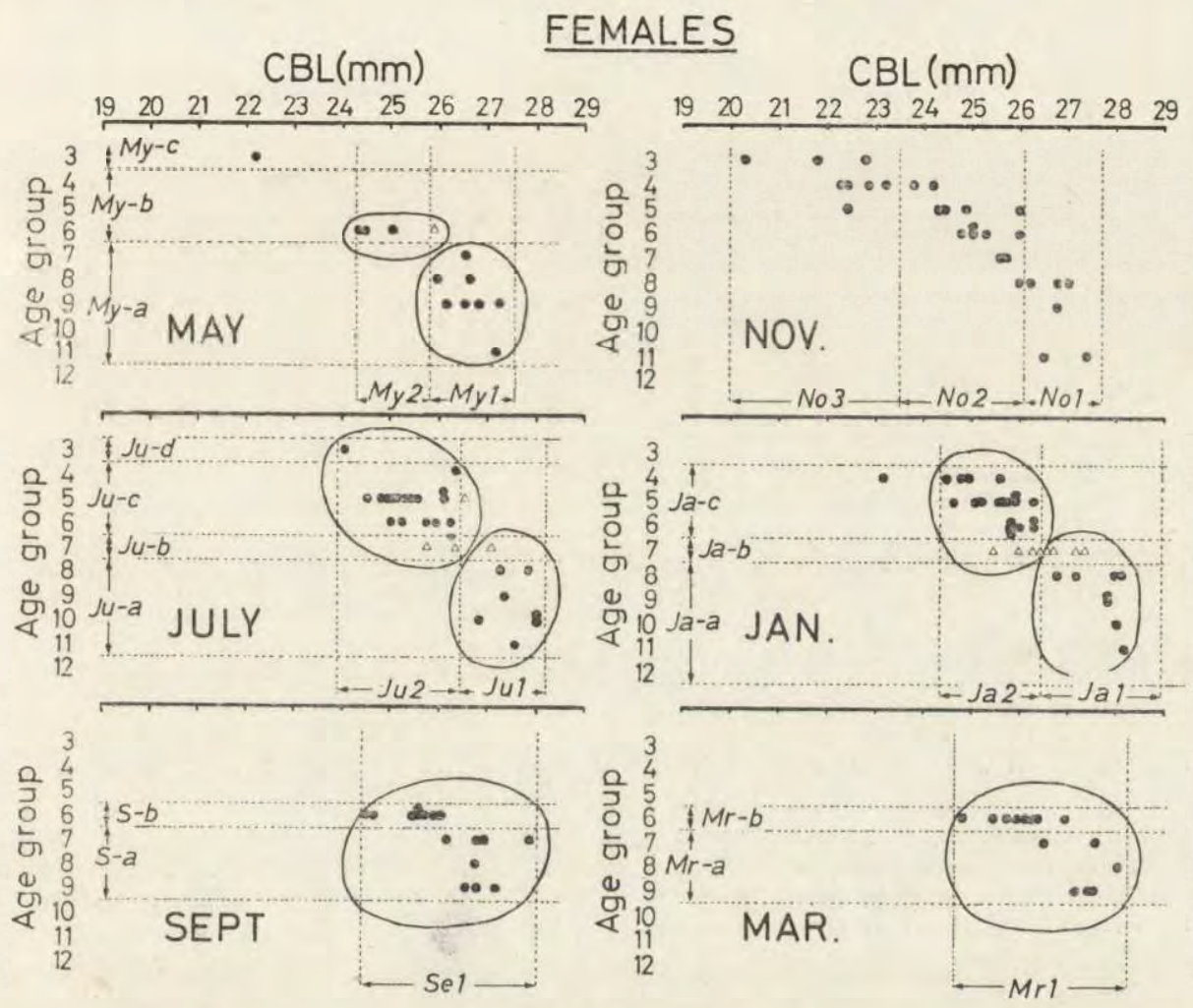

Fig. 4. Continued.

different times of the year (A $\mathrm{damczewska}$ 1961). It is suggested that females survived males by a few months in both generations (Fig. 5, 6 and 7).

\section{ABSOLUTE GROWTH}

Sexual differences were observed in the same generation in the following characters (Fig. 5, 6 and 7): the means of $H \& B L, B W, C B L$, $C-M^{1}$ and $C-Z$ were larger in males than in females of the same age, though females were almost equal to males in final mean cranial sizes. 


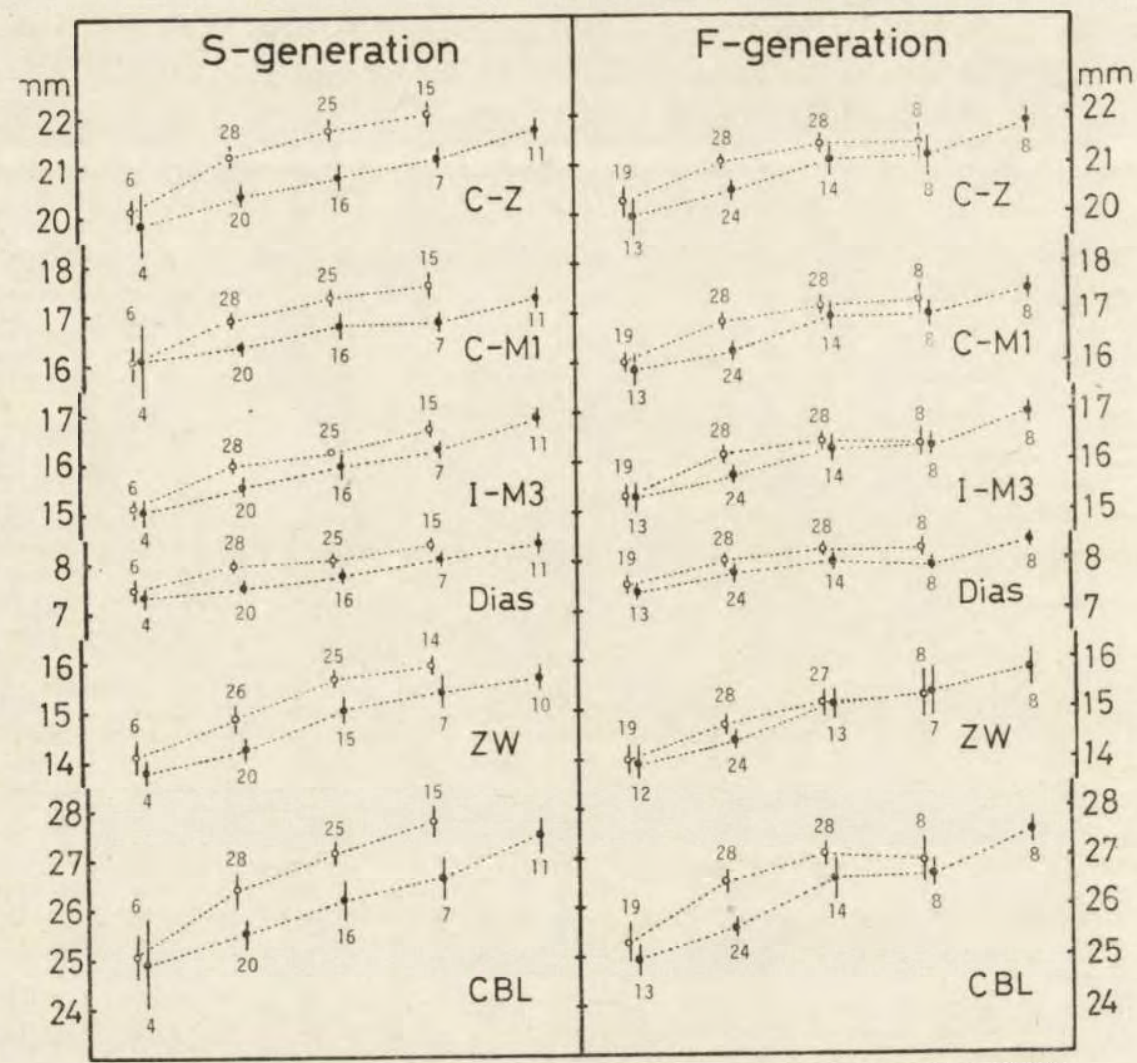

MAY JULY SEPT. NOV. JAN. NOV. JAN. MAR. MAY JULY

Fig. 5. Mean growth curves of Microtus montebelli born in spring (S-generation) and in fall (F-generation).

Solid lines and open symbols show males. Broken lines and solid symbols exhibit females, The vertical lines show the 95 per cent confidence limits for the mean. The number to the upside of the vertical line is the size of male samples, and that to the downside is the size of female ones.

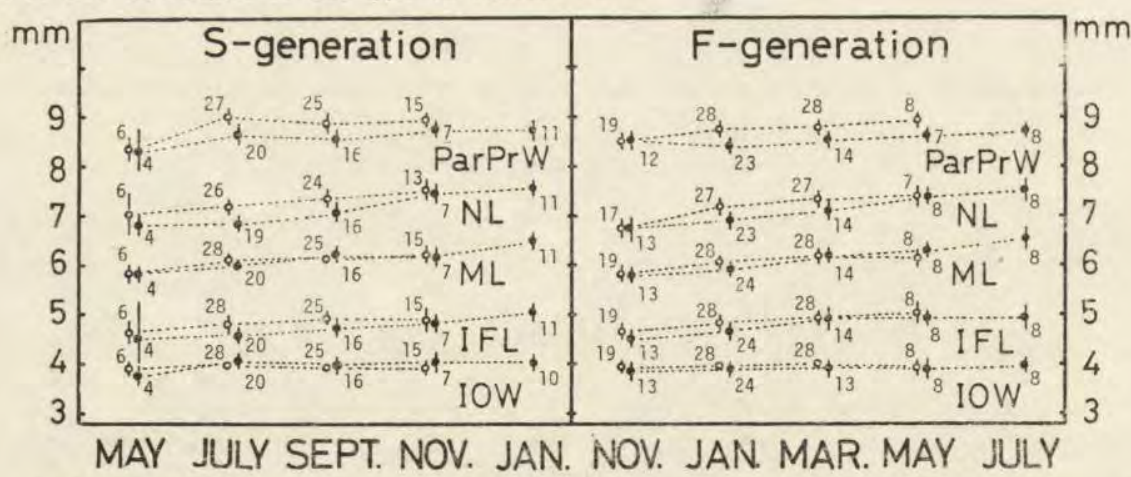

Fig. 6. Mean growth curves of Microtus montebelli born in spring (S-generation) and in fall (F-generation). Further explanations were given in Fig. 5. 
The growth rate of these measurements was greater in males than in females. The means of $H F L, E L$ and IOW remained nearly the same size through their lives. The mean growth of other external and cranial measurements in both sexes went on through their lives, and each mean size in males was slightly larger than that of females of the same age, though 95 per cent confidence limits of the mean were overlapped between both sexes.

In both sexes of S-generation, the growth of $H \& B L$ and $B W$ decreased or did not change from September to November, while the growth of several cranial dimensions except $C r a W, M L, I F L$ and $I O W$ continued through their lives. In both sexes of F-generation, the sizes of all the cranial measurements showed no growth at all from March to May, whereas $H \& B L$ and $B W$ increased during these periods.

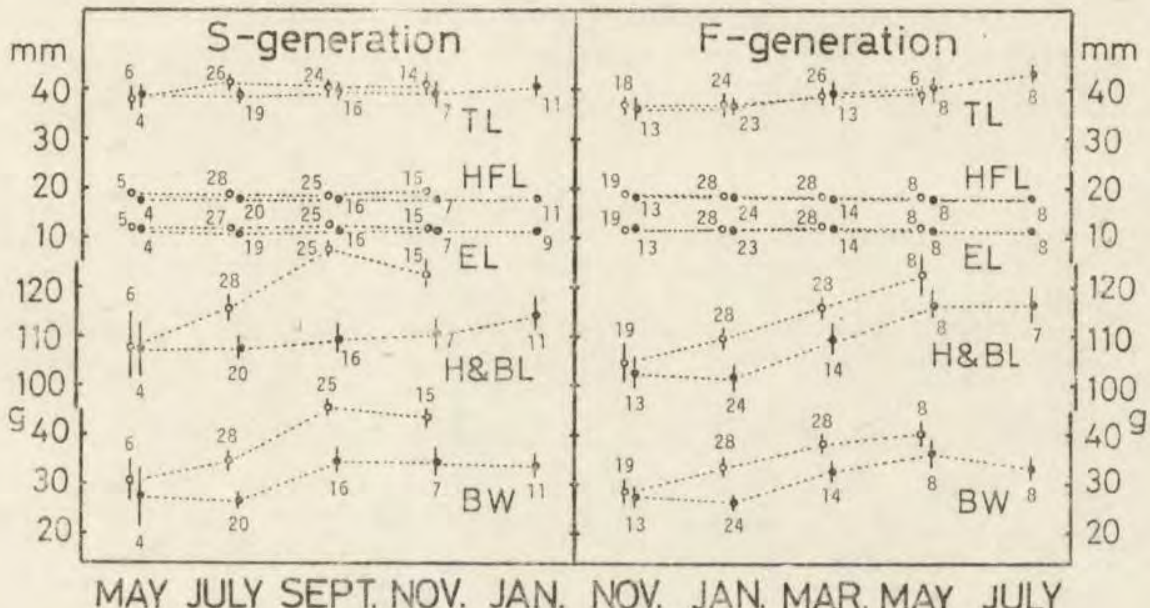

Fig. 7. Mean growth curves of Microtus montebelli born in spring (S-generation) and in fall (F-generation). Further explanations were given in Fig. 5.

The mean size of S-generation increased at a faster rate than that of $\mathrm{F}$-generation in male $C-Z$ and $C-M^{1}$. On the other hand, the mean size of $\mathrm{F}$-generation grew more rapidly than that of $\mathrm{S}$-generation in male $I-M^{3}$ and Dias at the initial period.

It will be seen from Fig. 5, 6 and 7 that the differences in absolute growth rates between both sexes in S-generation were generally greater than the differences between both sexes in F-generation. Furthermore, the differences between the two generations of males were greater in almost all characters than between the two female generations. It appears from these findings that the growth rate of male S-generation was the largest compared with the other three growth curves: i.e., male F-generation, female $\mathrm{S}$-generation and female $\mathrm{F}$-generation. 


\section{RELATIVE GROWTH}

The change in relationships between the dimensions of two body parts was given in a mathematical formation by $\mathrm{Huxley}$ (1924). If $X$ represents the size of a whole and $Y$ the size of a part, the relation between the two may be approximated by: $Y=b X^{a}$. The constant $a$ is termed the relative growth rate, and $b$ is termed the initial growth index. According to $\mathrm{R}$ e eve (1940), there occur two main sorts of

Table 1

Relative growth rates with their standard errors and formulas for regression of various dimensions of both sexes in two different generations in Microtus montebelli.

\begin{tabular}{|c|c|c|c|c|c|}
\hline & Generation & $\mathrm{N}$ & $\begin{array}{c}\text { Relative } \\
\text { growth rate } \\
a \pm S a\end{array}$ & $\begin{array}{r}\text { Regression } \\
\log \mathrm{Y}=a \log \end{array}$ & $\begin{array}{l}\text { equation } \\
X+\log b\end{array}$ \\
\hline \multirow{3}{*}{$H \& B L-B W$} & & & Males & & \\
\hline & Spring & 74 & $2.562 \pm 0.158$ & $\log Y=2.562$ & $\log X-3.738$ \\
\hline & Fall & 81 & $2.246 \pm 0.148$ & $\log Y=2.246$ & $\log X-3.064$ \\
\hline \multirow[t]{2}{*}{$C B L-Z W$} & Spring & 71 & $1.140 \pm 0.078$ & $\log Y=1.140$ & $\log X-0.445$ \\
\hline & Fall & 82 & $1.187 \pm 0.087$ & $\log Y=1.187$ & $\log X-0.520$ \\
\hline \multirow[t]{2}{*}{$C B L-C-Z$} & Spring & 74 & $0.903 \pm 0.033$ & $\log Y=0.903$ & $\log X+0.042$ \\
\hline & Fall & 83 & $0.883 \pm 0.027$ & $\log Y=0.883$ & $\log X+0.066$ \\
\hline \multirow[t]{2}{*}{$C B L-C-M^{1}$} & Spring & 74 & $0.915 \pm 0.031$ & $\log Y=0.915$ & $\log x-0.073$ \\
\hline & Fall & 83 & $0.960 \pm 0.029$ & $\log Y=0.960$ & $\log x-0.140$ \\
\hline \multirow[t]{2}{*}{$C B L-I-M^{s}$} & Spring & 74 & $0.865 \pm 0.040$ & $\log Y=0.865$ & $\log X-0.027$ \\
\hline & Fall & 83 & $0.926 \pm 0.036$ & $\log Y=0.926$ & $\log X-0.111$ \\
\hline \multirow[t]{2}{*}{ CBL-Dias } & Spring & 74 & $1.130 \pm 0.061$ & $\log Y=1.130$ & $\log x-0.709$ \\
\hline & Fall & 83 & $1.251 \pm 0.059$ & $\log Y=1.251$ & $\log X-0.876$ \\
\hline \multirow{3}{*}{$H \& R I,-B W *$} & & & Females & & \\
\hline & * Spring & 58 & $2.229 \pm 0.247$ & $\log Y=2.229$ & $\log X-3.079$ \\
\hline & Fall & 67 & $1.897 \pm 0.181$ & $\log Y=1.897$ & $\log x-2.380$ \\
\hline \multirow[t]{2}{*}{$C B L \cdot Z W$} & Spring & 56 & $1.139 \pm 0.093$ & $\log Y=1.139$ & $\log x-0.443$ \\
\hline & Fall & 64 & $1.284 \pm 0.079$ & $\log Y=1.284$ & $\log x-0.651$ \\
\hline \multirow{2}{*}{$C B L-C-Z$} & Spring & 58 & $0.873 \pm 0.028$ & $\log Y=0.873$ & $\log X+0.079$ \\
\hline & Fall & 67 & $0.930 \pm 0.032$ & $\log Y=0.930$ & $\log X+0.001$ \\
\hline \multirow{2}{*}{$C B L-C-M^{1}$} & Spring & 58 & $0.831 \pm 0.036$ & $\log Y=0.831$ & $\log X+0.043$ \\
\hline & Fall & 67 & $1.030 \pm 0.031$ & $\log Y=1.030$ & $\log X-0.240$ \\
\hline \multirow{2}{*}{$C B L-I-M^{3}$} & Spring & 58 & $1.101 \pm 0.046$ & $\log Y=1.101$ & $\log X-0.358$ \\
\hline & Fall & 67 & $0.966 \pm 0.038$ & $\log Y=0.966$ & $\log x-0.165$ \\
\hline \multirow[t]{2}{*}{ CBL-Dias } & Spring & 58 & $1.335 \pm 0.065$ & $\log Y=1.335$ & $\log X-1.002$ \\
\hline & Fall & 67 & $1.046 \pm 0.063$ & $\log Y=1.046$ & $\log x-0.588$ \\
\hline
\end{tabular}

* Body weight subtracting the weight of embryos was used as that of each pregnant female.

differences bētween samples of relative growth measurements. (1) The average relative growth rates; measured by the slopes of the allometry lines, may differ. Differences of this type are called "differences in slope" by Reeve. (2) The average size of one sample may be larger than in another for each body size, regardless of differences in relative growth rates. Differences of this nature are named "differences in position". Tests were first made for slope differences. If no significant differences 
in slope showed up both between two generations and between two sexes, a test for positional differences was done.

Relative growth rates and formulas for regression were shown in Table 1. Comparing male regression lines with females lines and S-generation regression lines with F-generation lines (Fig. 8), respectively,

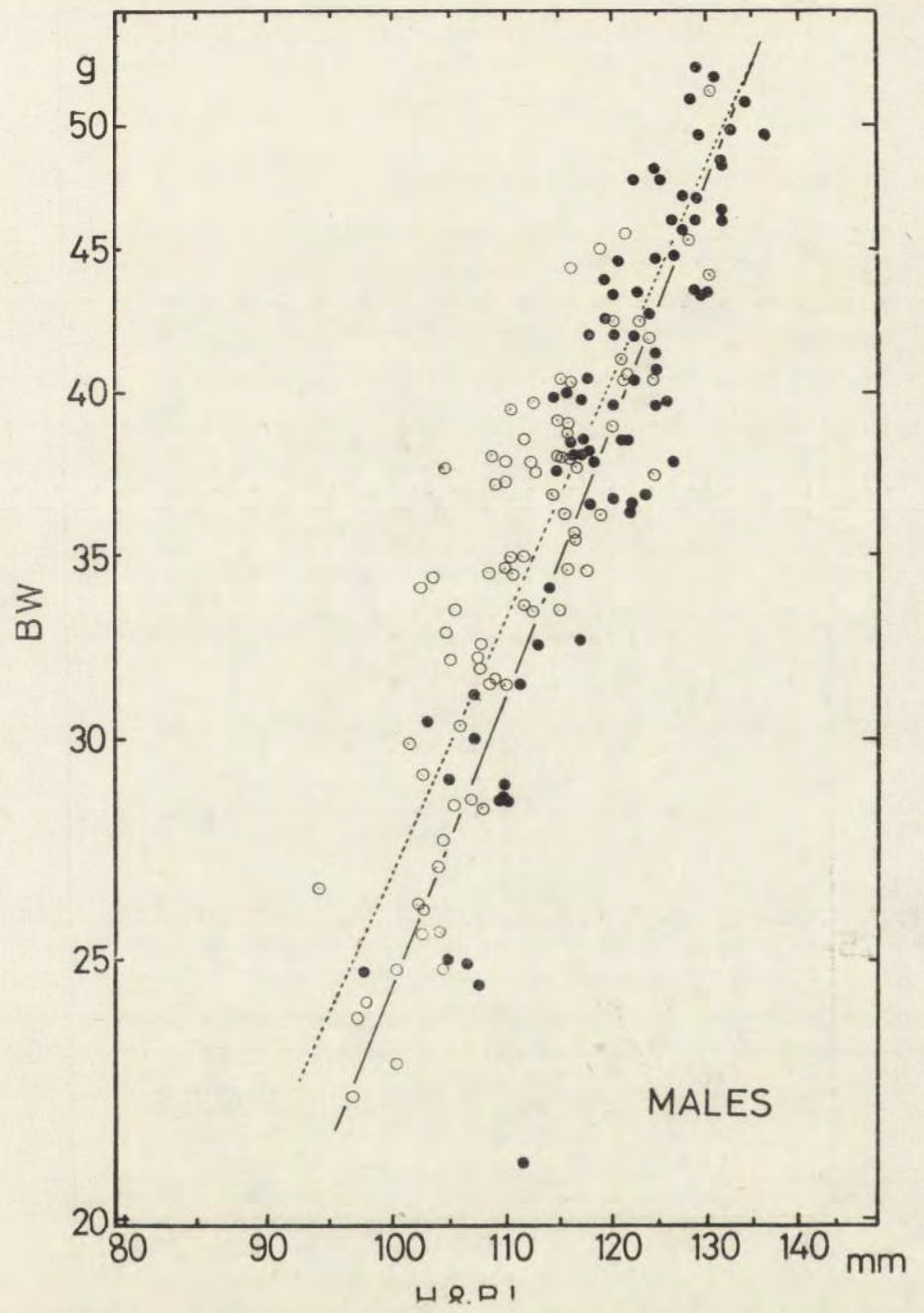

Fig. 8. Relative growth curves of two generations in each sex of Microtus montebelli.

The scale on both axes is logarithmic. In each growth curve, the $X$ axis and $Y$ axis are as given. Solid circles and solid line represent spring born specimens (S-generation), and open circles and broken line show fall born specimens (F-generation). 
the relationships between two lines were arranged in six types (Fig. 9). Slope differences were insignificant in all allometries $(p>0.10)$, while position differences were significant in several measurements both between the two generatons and between two sexes. The results of the type described above and the test of position differences are diagrammatically

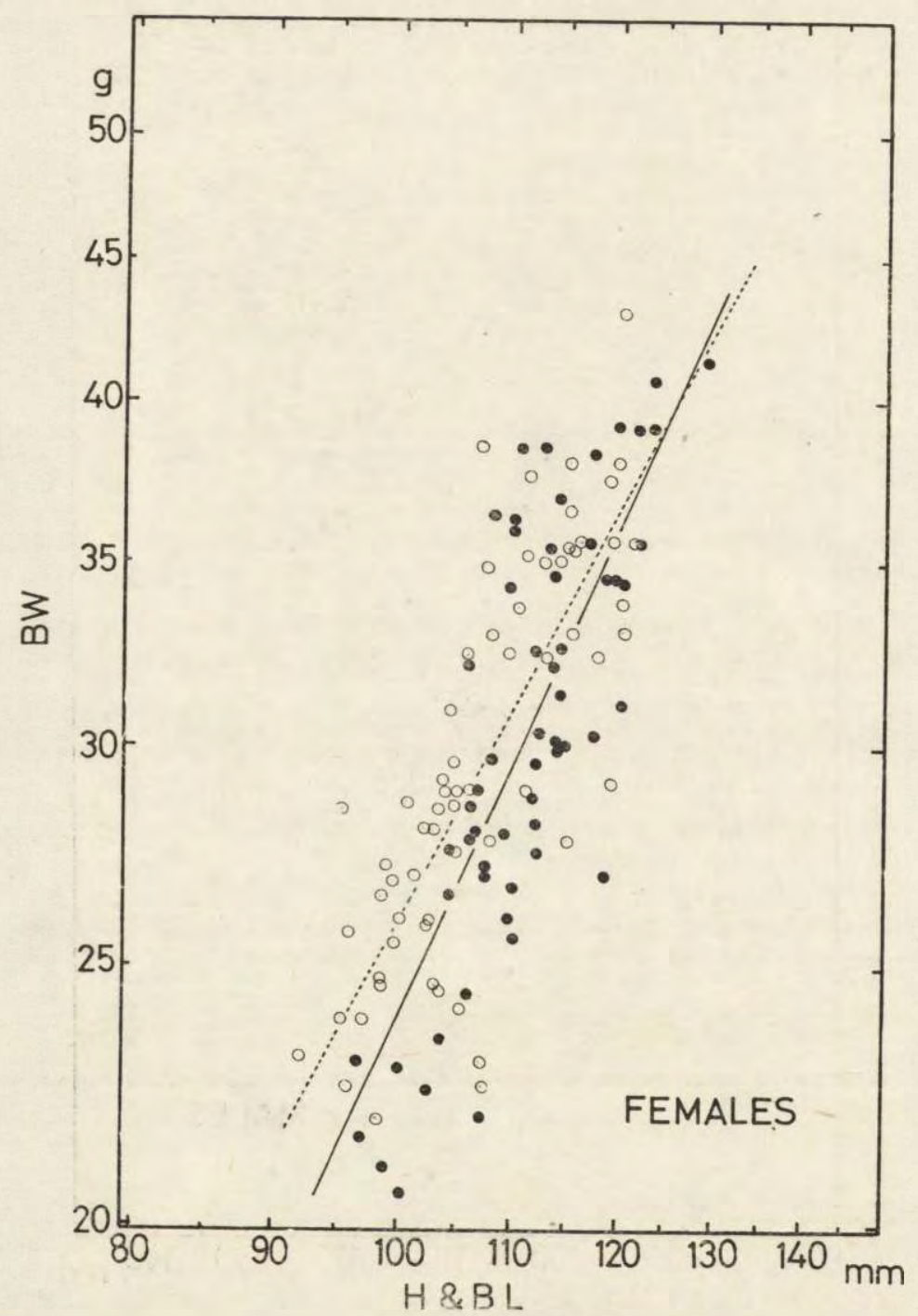

Fig. 8. Continued.

summarized in Fig. 10. Fig. 10 shows the following tendencies: most of the sexual differentiation is shown in a increase in $H \& B L$ and $C B L$ (II type and R-II type), and other sexual differences are statistically insignificant in position differences (III type and R-III type). There 


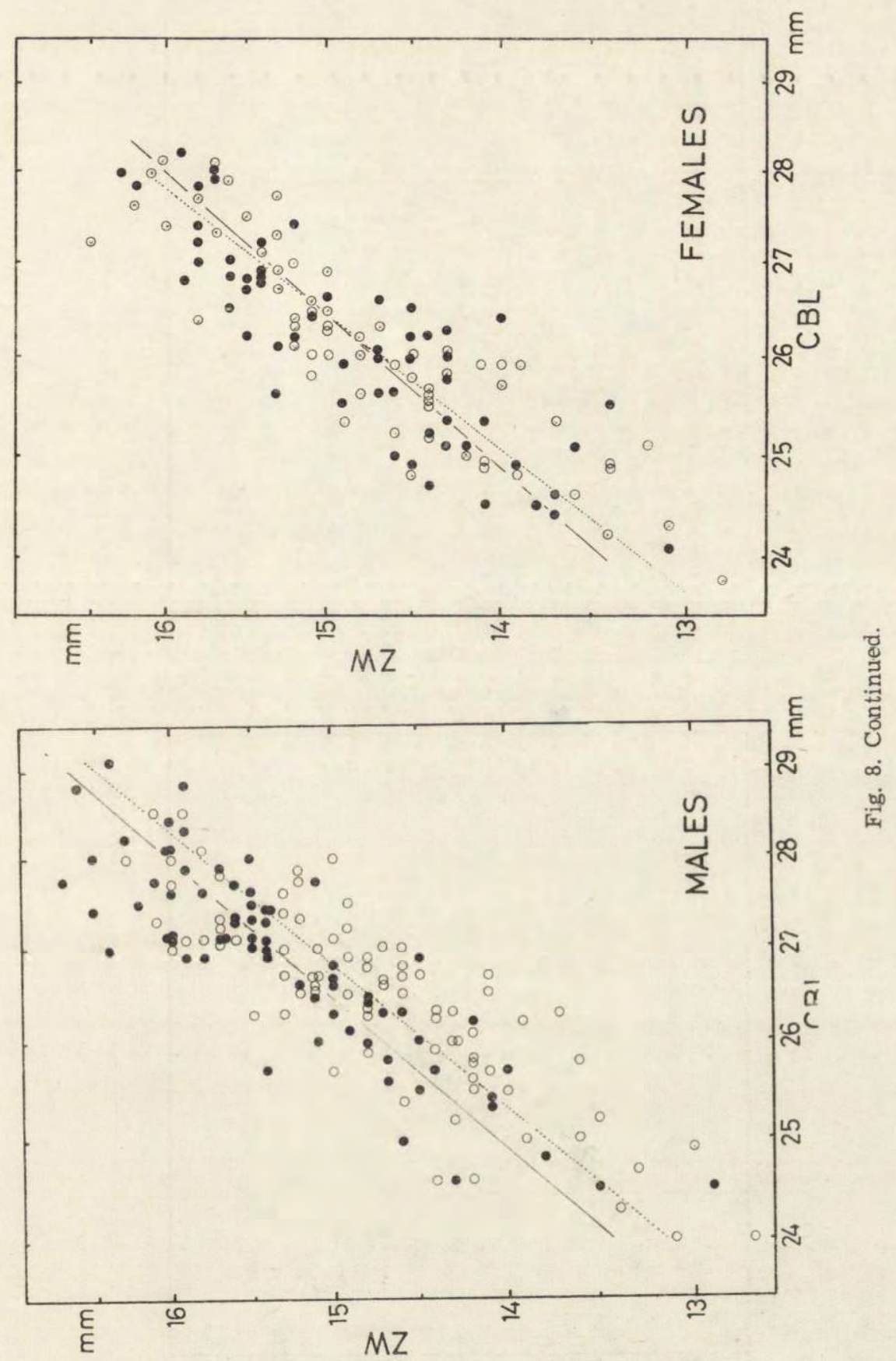



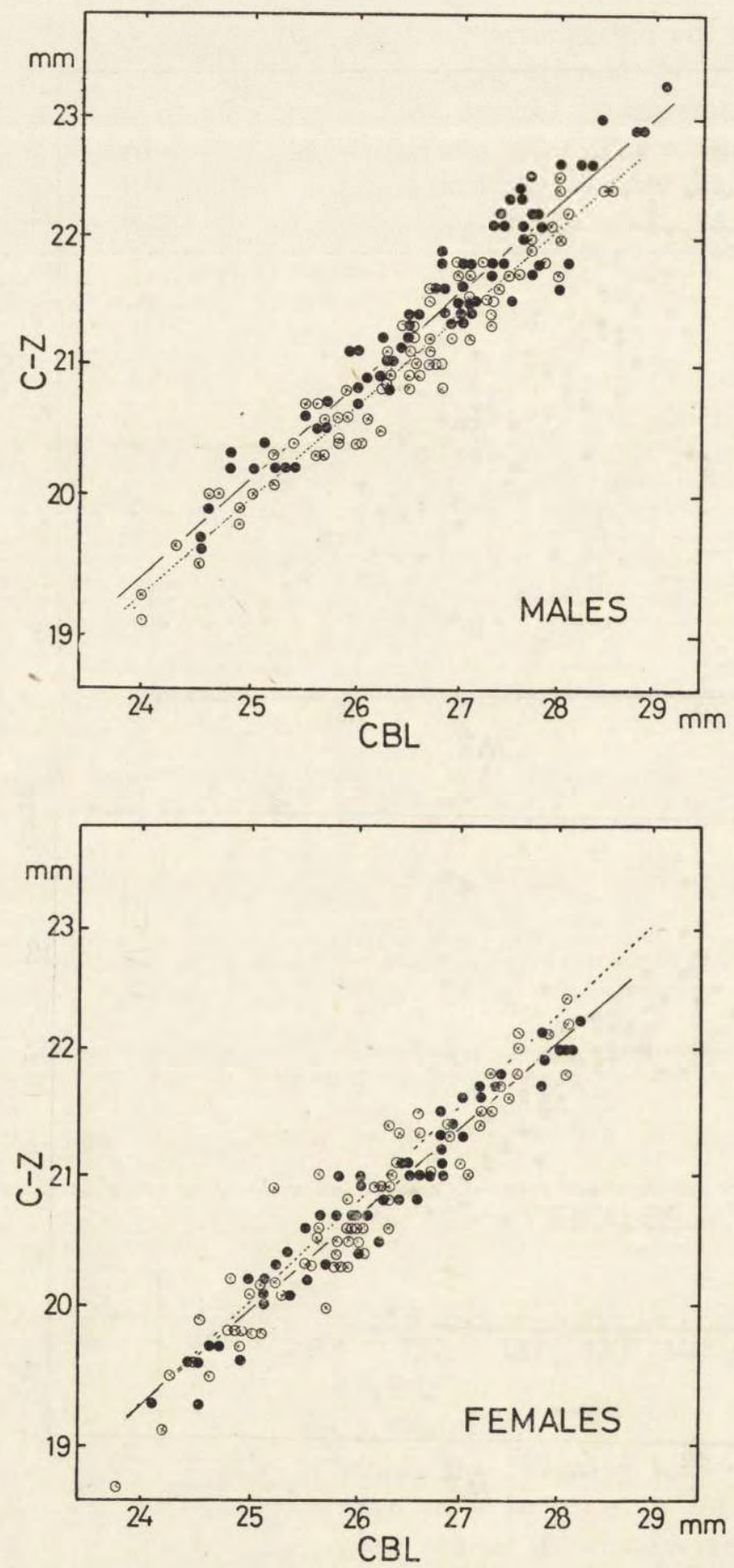

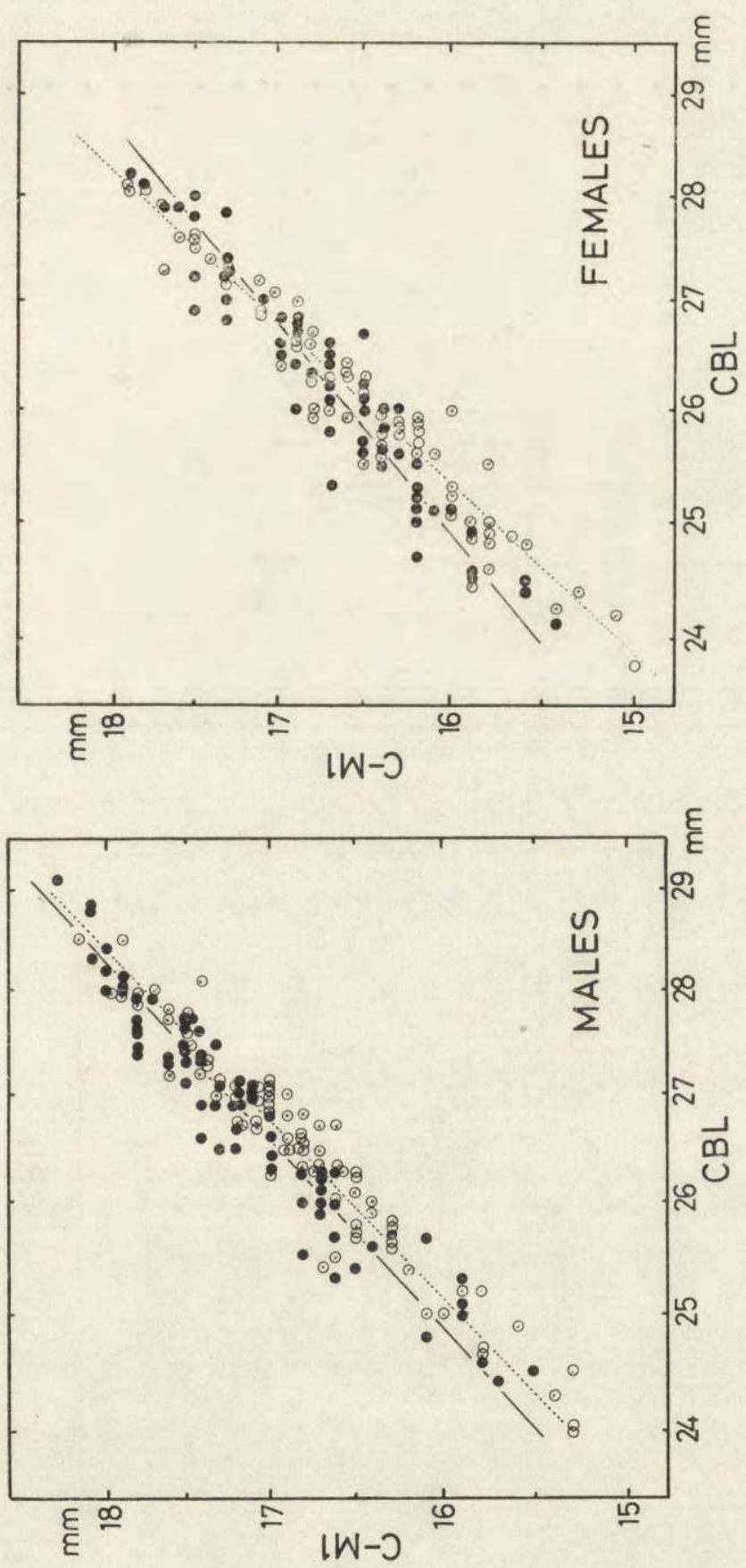

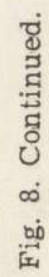



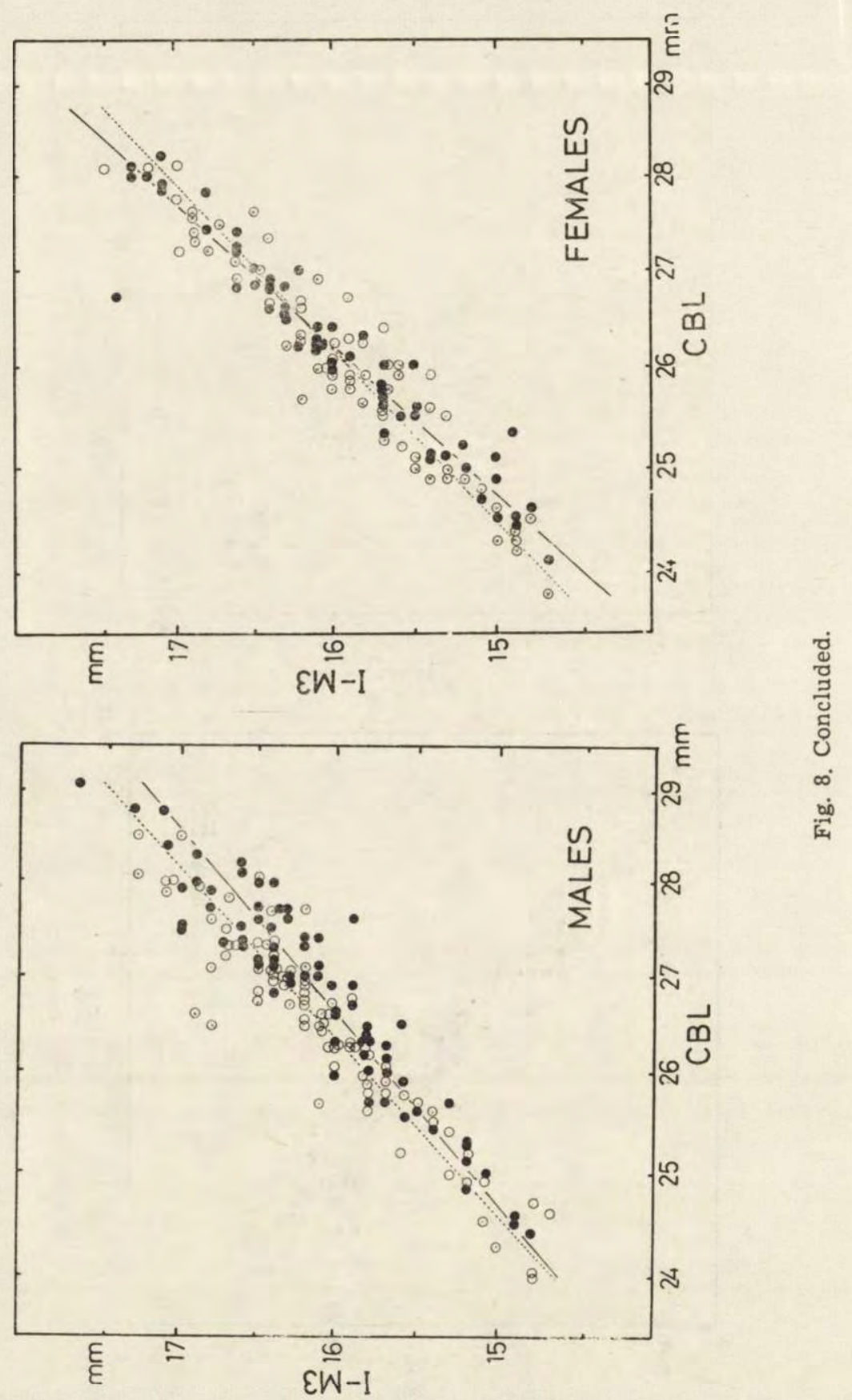
were statistical seasonal differences in all male relative growth. In I and II types the regression lines in S-generation lie more towards the upper side than in F-generation. In R-I and R-II types the lines in S-generation are placed more towards the lower side than in F-generation. The former types were found in such cranial dimensions as $Z W-C B L$ and $C-M^{1}-C B L$. There were statistically significant seasonal differences in such female characters as $B W-H \& B L, C-M^{1}-C B L$ and Dias-CBL.

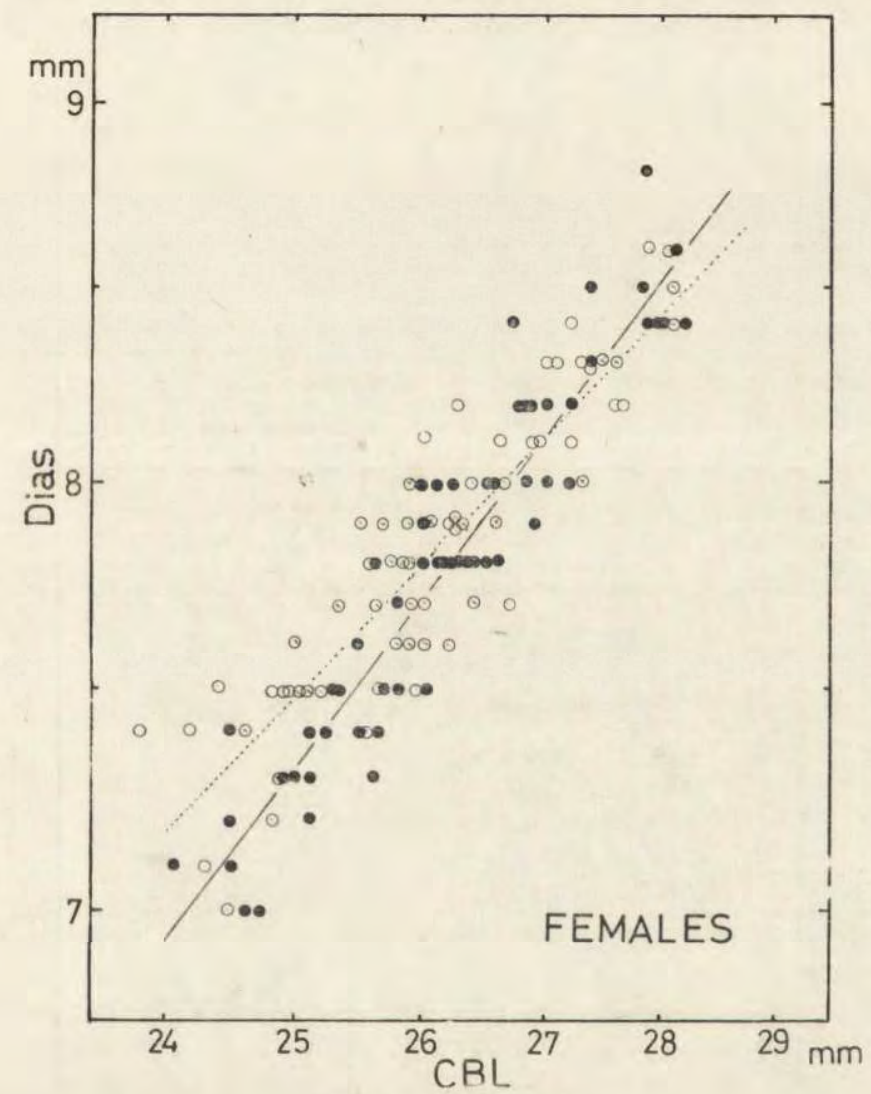

Fig. 8. Continued.

7. DISCUSSION

The previous paper ( $\mathrm{K}$ a neko, 1976) showed that the reproduction of the vole at Iwakura occurred primarily in spring and fall with sporadic breeding during winter, and an aestival intermission. Absolute growth analysis in the present study showed that only two growth curves were found in the Iwakura population, in spite of using the same specimens as the previous paper. This indicates that young voles born in winter were so few in number as considered in the previous 
paper that these voles were unable to be separated from either S-generation or F-generation. Spring and fall reproduction began in March and September, respectively, at Iwakura ( $\mathrm{K}$ a n e k o, 1976), and the two growth curves began in May and November, respectively. It follows that the animals in May and November belonged to the first stage of these curves, respectively (Fig. 5, 6 and 7), are regarded as one or two months age. The tail length of the vole in laboratory showed no growth from the 27 th to 40 th day after birth (Shiraishi, 1969;

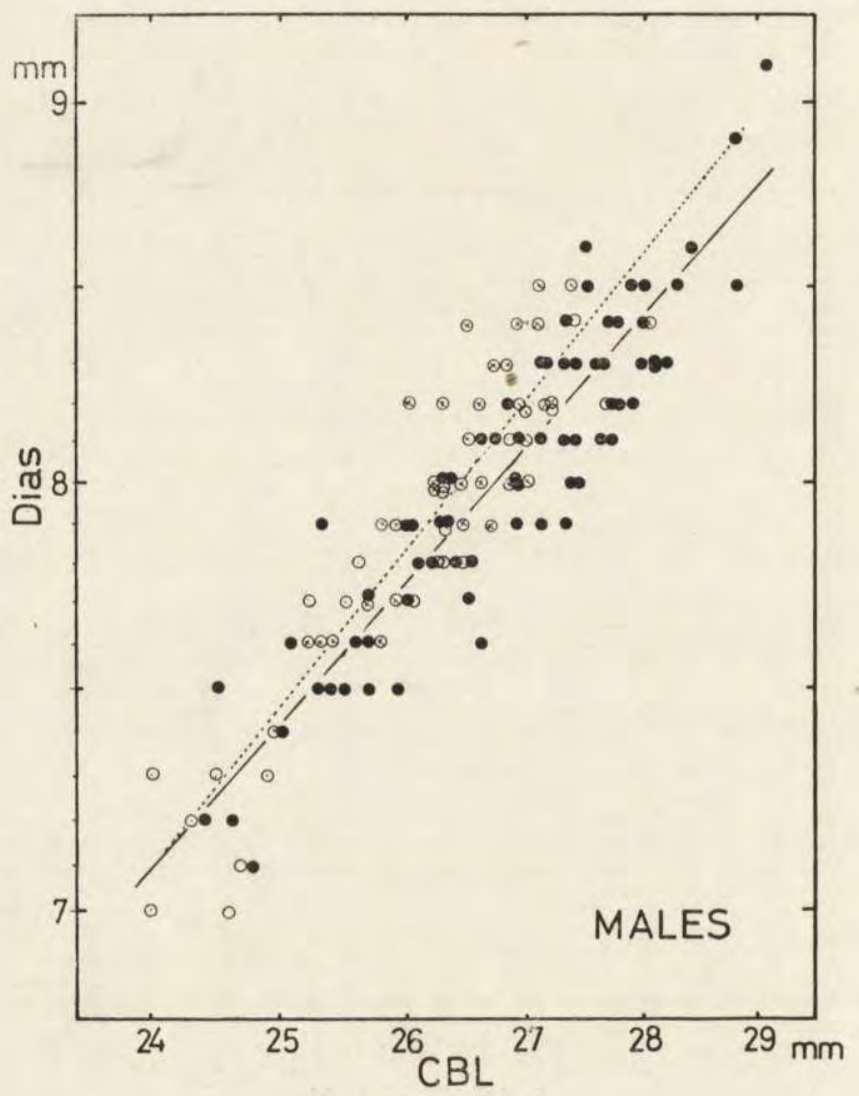

Fig. 8. Continued.

$\mathrm{O} \mathrm{b}$ a r a, 1975). As the mean tail length did not grow from May and November, respectively, in this work, the estimated age of these May and November animals does not contradict those laboratory data.

Since the young of $M$. arvalis appeared through the year, Martinet et al. (1971) were able to study seasonal growth changes in every month and in all seasons using the eye lens as an age indicator. In this study the separation of S-generation from F-generation was carried out using 
bi-monthly samples. Hence, the seasonal growth changes can be easily considered in correlation with the differences of growth in sexes.

In the present study, almost all external and cranial mean sizes were larger in males than in females. Therefore, the external growth is closely correlated with the skull growth in this vole. The sexual differences of the mean sizes were generally greater in S-generation than in F-generation (Fig. 5, 6 and 7). According to $\mathrm{Ku} \mathrm{bik}$ (1965) and $\mathrm{Zejda}$ (1971), sexual differences in body weight and lenth were greater in spring born animals than in summer and fall born animals in Clethrionomys glareolus, though females were greater than males in spring. P inter (1968) found in M. montanus that significant sexual dimorphism in growth rate of body weight and total length existed in postpubertial animals under the 18-hr photoperiod. Furthermore, he showed that, under a long photoperiod and with fresh greens in the

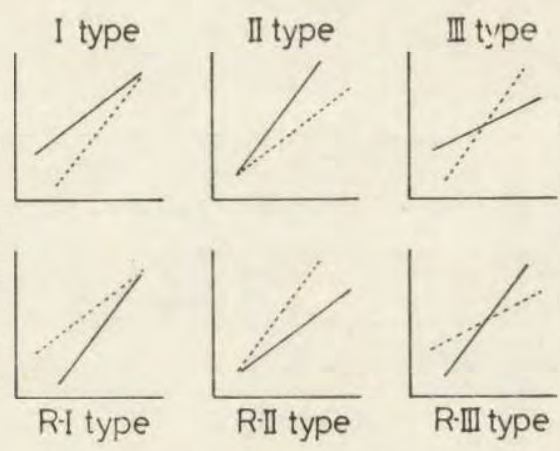

Fig. 9. Six types of the relationship between two regression lines.

Comparing male line with female line and S-generation line with F-generation line in the same dimension or weight in Fig. 8, the relationship is classified int? one of the six types. R-I, R-II and R-III types are opposite to I, II and III types, respectively, in the position of the relation between a solid line and a broken line. When a regression line in males is compared with that in females in the same generation, males are represented by a solid line and females are shown by a broken line. When a regression line in S-generation is compared with that in $\mathrm{F}$-generation, S-generation is indicated by a solid line and F-generation is exhibited by a broken line.

diet, the more rapidly growing males maintained a higher body weight and a greater total length than offspring in any of the other experimental regimes. Therefore, it is concluded that both fresh greens and a long photoperiod exerted an influence on the sexual dimorphism in body weight and length in spring born voles, though the sex of greater individuals in spring does not agree between Microtus and Clethrionomys.

The growth curves of $C-Z$ and $C-M^{1}$ (Fig. 5) showed sexual difference. 
Since there was no sexual difference in the growth of molar length $(M L)$, the difference arises from that in the size of braincase. The sizes of the two measurements, viz., $C-Z$ and $C-M^{1}$, were larger in males than in females in both generations. Furthermore, the oldest figure of age-group in males was class twelve, while the oldest in females was class eleven (Fig. 4). These findings show that compared with females the braincase parts in males are hypermorphic, as the posterior

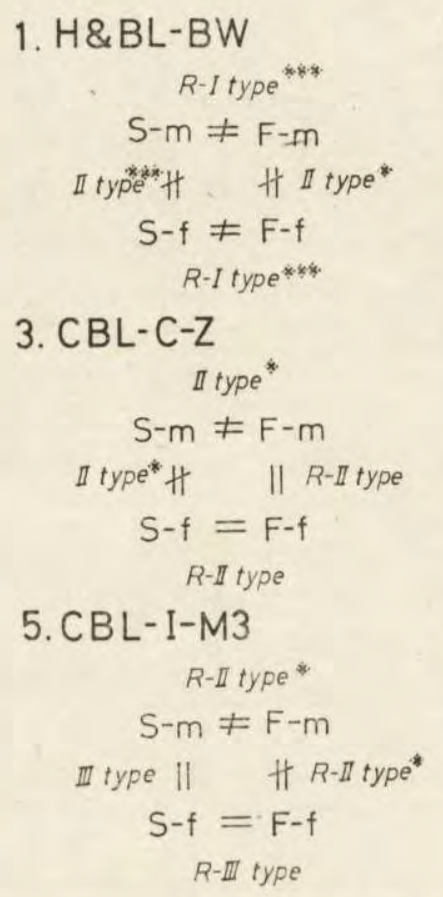

2. $C B L-Z W$

$$
\begin{gathered}
\text { Itype* } \\
\mathrm{S}-\mathrm{m} \neq \mathrm{F}-\mathrm{m} \\
\text { R-II type } \| \quad \# \text { R-II type* } \\
\mathrm{S}-\mathrm{f}=\mathrm{F}-\mathrm{f} \\
\text { II type }
\end{gathered}
$$

4. CBL-C-M1

$$
\text { Itype* }
$$$$
S-m \neq F-m
$$$$
\text { II type* + II II type }
$$$$
S-f \neq F-f
$$$$
\text { II type* }
$$

6. CBL-Dias

$$
\begin{gathered}
R-I \text { type * } \\
\mathrm{S}-\mathrm{m} \neq \mathrm{F}-\mathrm{m} \\
\text { III type }\|\quad\| R-\text { II type } \\
\mathrm{S}-\mathrm{f} \neq \mathrm{F}-\mathrm{f} \\
R-\mathbb{I I} \text { type ** }
\end{gathered}
$$

Fig. 10. Relationships among four regression lines in several dimensions and weight.

Illustration of six types is shown in Fig. 9. S-m: line of S-generation in males; $\mathrm{F}-\mathrm{m}$ : line of F-generation in males; $\mathrm{S}-\mathrm{f}$ : line of S-generation in females; F-f: line of $\mathrm{F}$-generation in females; $=$ : statistically insignificant in position differences; $\neq:$ statistically significant in position differences $(*: p<0.005 ; * *$ : $0.005<p<0.01$; ***: $0.01<p<0.025)$.

part of skull develops larger process and crests as well as showing greater overall dimensions.

There were statistically significant seasonal differences in relative growth in male cranial dimensions in the present study. The relationship of regression lines between two generations in male $I-M^{3}$ and Dias against CBL showed R-II type (Fig. 10): the regression line in F-generation lay more towards the upper side than in S-generation. Moreover, 
the absolute growth rate of $I-M^{3}$ and Dias found to be slightly larger in F-generation than in S-generation at the initial period (Fig. 5). Since there was no seasonal difference in male $M L$, the greater growth rate of $I-M^{3}$ in male $\mathrm{F}$-generation is due to that of diastema. A d a mc zewska-Andrzejewska (1973b) found in Apodemus agrarius that the diastema increased more intensively in winter than $C B L$. It follows that the diastema part in males grows greatly in F-generation than in S-generation in the same size of $C B L$.

The absolute sizes of male $C-Z, C-M^{1}$ and $Z W$ grew more rapidly in $\mathrm{S}$-generation than in $\mathrm{F}$-generation through their lives (Fig. 5). The relationship of regression lines between two generations in male $C-Z$, $C-M^{1}$ and $Z W$ against $C B L$ showed either I or II types (Fig. 10). B e e \& $\mathrm{H}$ a 11 (1956) wrote that seasonal generations of C. rutilus, M. oeconomus and $M$. miurus in Alaska differed in skull proportions. Since the line in S-generation lay more towards the upper side than in F-generation in I and II types, the braincase part and zygomatic width of males increased greatly in S-generation than in F-generation in the same size of $C B L$. From the conclusion mentioned above, it seems possible that the hypermorposis of the braincase in male S-generation was effected by both greens and long photoperiods.

The finding of smaller growth rate of braincase of male F-generation in $M$. montebelli is somewhat similar to the phenomenon of depression or narrowing of the braincase in several small mammals during winter, which has been reported in A. agrarius ( $\mathrm{H}$ a it 1 inge $\mathrm{r}, 1962$ ), C. alareolus (Haitlinger, 1965) and Sorex araneus (Dehnel, 1949). P u cek (1970) described a depression of cranial heigth in Sorex that was caused by the resorption of occipital and parietal bones because of the presence of osteoclasts. Since histological studies of voles' cranium have not been made as yet, the mechanism of smaller growth rate of braincase in male F-generation in the present vole is open to question.

The decrease in male $H \& B L$ from September through November (Fig. 7) may probably be the result of two processes: death of the larger animals and cessation of growth in the younger. The cranial growth bf the vole stopped from March to May in F-generation, while the mean growth of $B W$ and $H \& B L$ increased slightly during these periods (Fig. 5 and 7). As the growth of $H \& B L$ ceased during winter in $M$. arvalis ( $\mathrm{M}$ a rtinet et al., 1971), the reason for this disagreement leaves the question untouched.

Females showed smaller seasonal variation than males in both absolute and relative growth. K a n e ko (1978) reported variations of external and cranial measurements between neighboring October populations in two types of habitats. In the report the absolute sizes in females showed 
no statistically significant differences between the two habitats, while there were significant differences in male size and weight. Therefore, it is suggested that the environmental conditions, which are derived from both seasonal and habitat differences, have little effect upon the sizes of females.

Since there were seasonal differences between two generations in relative growth, especially in males, the results by Snyder (1954) and Peshev (1970) who compared geographical variation of relative growth among samples taken during different seasons, are open to question.

Further growth study will be needed in the young voles from parturition until weaning and/or in embryos, especially in such $I$ and R-I types as $B W-H \& B L, Z W-C B L$ and $C-M^{1}-C B L$ (Fig. 10).

Acknowlergements: This paper was taken from parts of the doctoral thesis of Y. Kaneko, Kyoto University, 1974. I wish to thank to Mr. J. K ing d on and Professor E. W. J a m e s on, Jr, for reading and criticizing the manuscript, and to the late Dr. M. Tok u d a for his encouragement. I am also grateful for many helpful discussions from the following: Dr. M. Morishita, Mr. O. Murakami, Dr. T. Sunaga, Dr. T. Uematsu, Dr. M. Tasumi, Dr. H. Tabata, Dr. K. Wada, Dr. T. Kobayashi and Dr. Y. Fujimaki.

\section{REFERENCES}

1. Adamczewska K. A., 1961: Intensity of reproduction of the Apodemus flavicolis (Melchior 1834) during the period 1954-1959. Acta theriol., 5: $1-21$.

2. Adamczewska-Andrzejewska K. A., 1973a: The lens weight as indicator of age in the wild Microtus arvalis population. Bull. Acad. Pol. Sci. Cl. 2,

- 21: $331-336$.

3. A d a mczewska-Andrzejewska K. A., 1973b: Growth, variation and age criteria in Apodemus agrarius (P a 11 a s, 1771). Acta theriol., 18: 353-394.

4. B arbehenn K. R., 1955: A field study of growth in Microtus pennsylvanicus. J. Mammal., 36: 533-543.

5. Be e J. W. \& Hall E. R., 1956: Mammals of northern Alaska on the arctic slope. Univ. Kan .Mus. Nat. Hist. Misc. Publ., 8: 1-309. [Cited by Brown, E. B. III 1973].

6. Brown E. B., III, 1973: Changes in patterns of seasonal growth of Microtus pennsylvanicus. Ecology, 54: 1103-1110.

7. Cassie R. M., 1954: Some uses of probability paper in the analysis of size frequency distributions. Aust. J. Mar. Freshw. Res., 5: 513-522.

8. Dehnel A., 1949: Studies on the genus Sorex L. Ann. Univ. Marie Curie-Skłodowska Sect. C, 4: 17-102. [In Polish with English summary. Cited by Pucek, Z. 1970].

9. Evans D. M., 1973: Seasonal variations in the body composition and nutrition of the vole Microtus agrestis. J. Anim. Ecol., 42: 1-18.

10. Haitlinger R., 1962: Morphological variability in Apodemus agrarius ( $\mathrm{P}$ a 1la s, 1771). Acta theriol., 6: 239-255. 
no statistically significant differences between the two habitats, while there were significant differences in male size and weight. Therefore, it is suggested that the environmental conditions, which are derived from both seasonal and habitat differences, have little effect upon the sizes of females.

Since there were seasonal differences between two generations in relative growth, especially in males, the results by Snyder (1954) and Peshev (1970) who compared geographical variation of relative growth among samples taken during different seasons, are open to question.

Further growth study will be needed in the young voles from parturition until weaning and/or in embryos, especially in such $I$ and R-I types as $B W-H \& B L, Z W-C B L$ and $C-M^{1}-C B L$ (Fig. 10).

Acknowlergements: This paper was taken from parts of the doctoral thesis of Y. Kaneko, Kyoto University, 1974. I wish to thank to Mr. J. K ing d on and Professor E. W. J a m e s on, Jr, for reading and criticizing the manuscript, and to the late Dr. M. Tok u d a for his encouragement. I am also grateful for many helpful discussions from the following: Dr. M. Morishita, Mr. O. Murakami, Dr. T. Sunaga, Dr. T. Uematsu, Dr. M. Tasumi, Dr. H. Tabata, Dr. K. Wada, Dr. T. Kobayashi and Dr. Y. Fujimaki.

\section{REFERENCES}

1. Adamczewska K. A., 1961: Intensity of reproduction of the Apodemus flavicolis (Melchior 1834) during the period 1954-1959. Acta theriol., 5: $1-21$.

2. Adamczewska-Andrzejewska K. A., 1973a: The lens weight as indicator of age in the wild Microtus arvalis population. Bull. Acad. Pol. Sci. Cl. 2,

- 21: $331-336$.

3. A d a mczewska-Andrzejewska K. A., 1973b: Growth, variation and age criteria in Apodemus agrarius (P a 11 a s, 1771). Acta theriol., 18: 353-394.

4. B arbehenn K. R., 1955: A field study of growth in Microtus pennsylvanicus. J. Mammal., 36: 533-543.

5. Be e J. W. \& Hall E. R., 1956: Mammals of northern Alaska on the arctic slope. Univ. Kan .Mus. Nat. Hist. Misc. Publ., 8: 1-309. [Cited by Brown, E. B. III 1973].

6. Brown E. B., III, 1973: Changes in patterns of seasonal growth of Microtus pennsylvanicus. Ecology, 54: 1103-1110.

7. Cassie R. M., 1954: Some uses of probability paper in the analysis of size frequency distributions. Aust. J. Mar. Freshw. Res., 5: 513-522.

8. Dehnel A., 1949: Studies on the genus Sorex L. Ann. Univ. Marie Curie-Skłodowska Sect. C, 4: 17-102. [In Polish with English summary. Cited by Pucek, Z. 1970].

9. Evans D. M., 1973: Seasonal variations in the body composition and nutrition of the vole Microtus agrestis. J. Anim. Ecol., 42: 1-18.

10. Haitlinger R., 1962: Morphological variability in Apodemus agrarius ( $\mathrm{P}$ a 1la s, 1771). Acta theriol., 6: 239-255. 
11. Haitlinger R., 1965: Morphological analysis of the Wroclaw population of Clethrionomys glareolus (S chreber, 1780). Acta theriol., 10: 243-272.

12. Huxley J. S., 1924: Constant differential growth-ratios and their significance. Nature, 114: 895-896.

13. Kaneko Y., 1976: Reproduction of Japanese field voles, Microtus montebelli (Milne-Edwards), at Iwakura, Kyoto, Japan. Jap. J. Ecol., 26: 107-114.

14. K a n eko Y., 1978: A comparison of number of embryos and measurements of Microtus montebelli in two types of habitats. Acta theriol., 23: 140-143.

15. Kubik J., 1965: Biomorphological variability of the population of Clethrionomys glareolus (S c hre be r, 1780). Acta theriol., 10: 117-179.

16. Martinet L., 1966: Détermination de l'âge chez le Campagnol des champs (Microtus arvalis) par la pesée du cristallin. Mammalia, 30: 425-430.

17. Martinet L. \& Splitz F., 1971: Variations saisonnières de la croissance et de la mortalité du Sampagnol des champs, Microtus arvalis. Rôle du photopériodisme et de la végétation sur ces variations. Mammalia, 35: 38-84.

18. O b a r a I., 1975: Growth and development of Microtus montebelli. J. Mamm. Soc. Japan, 6: 107-114. [In Japanese with English abstract.].

19. Peshev Ts., 1970: Distribution and taxonomy of Microtus nivalis Martins in Bulgaria. Mammalia, 34: 252-268.

20. Pinter A. J., 1968: Effects of diet and light on growth, maturation, and adrenal size of Microtus montanus. Amer. J. Physiol., 215: 461-466.

21. Pokrovskij A. V., 1971: Seasonal changes in biological cycles in some rodents and the problem of absolute age determination. Ann. Zool. Fennici, 8: $94-96$.

22. Pucek Z., 1970: Seasonal and age change in shrews as an adaptive process. Symp. zool. Soc., London, 26: 189-207.

23. R e eve E. C. R., 1940: Relative growth in the snout of Anteaters. A study in the application of quantative methods of systematics. Proc. zool. Soc., London, Ser. A, 110: 47-80.

24. Schwarz S. S., Pokrovski A. V., Istchenko V. G., Olenjev V. G., Ovtschinnikova N. A. \& Pjastolova O. A., 1964: Biological peculiarities of seasonal generations of rodents with special reference to problem of senescence in mammals, Acta theriol., 8: 11-43.

25. Shiraishi S., 1969: [Growth of the Japanese vole, Microtus montebelli]. No. 80 Lec. Japanese Forest Soc.: 259-260. [In Japanese].

26. Simpson G. G., 1941: Large Pleistocene Felines of North America. Amer Mus. Novit., 1136: 1-27.

27. Snyder D. P., 1954. Skull variation in the meadow vole (Microtus p. pennsylvanicus) in Pennsylvania. Ann. Carnegie Mus,, 33: 201-234.

28. Southern H. N. ed., 1964: The handbook of British Mammals. Blackweli Sci. Publ.: $1-465$. Oxford.

29. T a st J., 1966: The root vole, Microtus oeconomus (Pallas), as an inhabitant of seasonally flooded land. Ann, zool. Fennici, 3: 127-171.

30. Zejda J., 1971: Differential growth of three cohorts of the bank vole, Clethrionomys glareolus Schreb. 1780. Zool. Listy, 20: 229-245.

Accepted, June 2, 1977. 
Yukibumi KANEKO

SEZONOWE I PECIOWE ZROŻNICOWANIA ABSOLUTNEGO I RELATYWNEGO WZROSTU MICROTUS MONTEBELLI

\section{Streszczenie}

Zmierzono wzrost $M$. montebelli, wyławianych dwa razy w ciągu miesiąca na polach uprawnych w Kyoto, w zachodniej części Honshu, w Japonii. Odłowy prowadzono od maja 1971 do marca 1972 r. Analizę tempa wzrostu przeprowadzono na podstawie pomiarów konwencjonalnych cech zewnętrznych i czaszkowych (Ryc. 1). Podziału każdej miesięcznej próby na generację sezonowe dokonano przez skorelowanie następujących metod: (1) wielomodalnego rozkładu częstości długości $\mathrm{Cb}$. z użyciem arytmetycznego prawdopodobieństwa i (2) wydzielania grup wiekowych na podstawie pomiarów ciała i wskaźników czaszkowych. Wykazano zróżnicowania w tempie wzrostu osobników urodzonych na wiosnę (S-generacja) i w jesieni (F-generacja) (Ryc. 5-7, Tabela 1), przy czym zróżnicowania absolutnego tempa wzrostu samic i samców S-generacji były o wiele większe niż w obrębie F-generacji (Ryc. 8). Zróżnicowania między samcami porównywanych generacji są znaczniejsze i bardziej charakterystyczne niż między samicami tych generacji. Najszybszym tempem wzrostu charakteryzują się samce S-generacji. W porównaniu z samicami mózgoczaszka samców jest hypermorficzna. U samców S- generacji jest ona większa niż u samców urodzonych jesienią. Na podstawie porównań relatywnego tempa wzrostu, opisanego równaniami regresji wyróżniono sześć typów równań (Ryc. 9) i przeanalizowano które z badanych cech $w$ istotny sposób wpływają na zróżnicowania sezonowe i dymorfizm płciowy (Ryc. 10). 